\title{
ANALYSIS OF DONOR DEFERRAL IN BLOOD DONORS
}

Nagarekha Kulkarni

1. Associate Professor, Department of Pathology, VIMS, Bellary, Karnataka,

\section{CORRESPONDING AUTHOR}

Dr. Nagarekha Kulkarni,

Associate Professor,

VIMS, Bellary,Karnataka.

E-mail: nagarekhakulkarni@gmail.com,

Ph: 00919449463366.

ABSTRACT: INTRODUCTION: A large number of blood donors are not able to donate blood successfully for several reasons, either temporarily or permanently. AIM:The present study was conducted to analyse the incidence and various reasons for deferrals. MATERIALS AND METHODS: The study was conducted at Medical College Hospital, Blood Bank during the period from January 2011 to December 2011.The study involved donors who have donated blood at outdoor voluntary blood donation camps and at the blood bank. Donors were selected by Medical officer. Information regarding the donor deferral was recorded. RESULTS: Three hundred (4.27\%) donors were deferred. Among them 236 (78.66\%) were VD and $64(21.34 \%)$ were RD. In the present study majority (46\%) of the donors deferred were between 18-28 years . Donor deferrals were tabulated into temporary and permanent. Temporary deferrals were 204(68\%) and permanent deferrals were 96(32\%). Among 204 (68\%) temporary deferrals, the most common cause was anemia (34.31\%), underweight (27.45\%). Among 96 (32\%) permanent deferrals, the most common cause was hypertension (48.96\%). CONCLUSION: The donor deferrals can be reduced by creating awareness and educating the donors.

KEY WORDS: donor deferral, temporary, permanent, anemia, under weight

INTRODUCTION: A blood transfusion is a life-saving procedure in many instances and it requires an adequate supply of safe blood. Many measures have been taken to make the blood transfusion safe by the blood transfusion committee. The most important is the selection of blood donors by donor selection criteria.[1] A large number of blood donors are not able to donate blood successfully for several reasons, either temporarily or permanently. Individuals disqualified from donating blood are known as 'deferred' donors. Blood donor deferral is a painful and sad experience for the blood donor as well as the blood center screening the donor. Deferring donors often leaves them with negative feelings, about themselves as well as the blood donation process. Additionally these donors are less likely to return for blood donation in future. ${ }^{[2]} \mathrm{A}$ few studies in India in the past have provided different common reasons for deferral of whole blood donation highlighting differing demographic profile in different parts of the country.[3]

AIM: The present study was conducted to analyze the incidence and various reasons for deferrals.

MATERIALS AND METHODS: The study was conducted at Medical College Hospital, Blood Bank during the period from January 2011 to December 2011.The study involved donors who have donated blood at outdoor voluntary blood donation camps and at the blood bank. Deferral by 
self and repeat donors were not included in the study. Each donor was examined by Medical Officer based on detailed medical history and brief physical examination as per the criteria laid down by Director General Health Services and Drug's Controller of India. ${ }^{[4]}$ Detailed information on the donor deferred including the age, sex, cause of deferral whether temporary or permanent were recorded. The quantity of blood collected was $350 \mathrm{ml}$ from donors weighed $>45 \mathrm{kgs}$ and $450 \mathrm{ml}$ from donors who weighed $>60 \mathrm{kgs}$. All the donors were screened by CuSo4 method for haemoglobin estimation $(\mathrm{Hb} \%)$ and the cut-off was $12.5 \mathrm{~g} / \mathrm{dl}$. The doubtful value for donors were confirmed by Shali's Haemoglobinometer method. Donors with systolic BP between 100 \& $180 \mathrm{~mm}$ of $\mathrm{Hg}$ and diastolic BP between 50-100 mm of Hg were accepted for blood donation. An average of three measurements were taken for those not falling within this range of systolic or diastolic BP.

RESULTS:During the study period the total number of donors accepted for blood donation were 7015 both in the outdoor voluntary blood donation camp and at the blood bank. Voluntary donors (VD) were 5823 (83\%) and relative donors (RD) were 1192(17\%). Male donors were 6825(97.22\%) and female donors were 190 (2.78\%).

Of the total donors who were willing for blood donation, $300(4.27 \%)$ donors were deferred. Among them 236 (79\%) were VD and 64 (21\%) were RD. In the present study majority (46\%) of the donors deferred were between 18-28 years followed by 29-38 years (28\%).The deferral among males were 196 (65.33\%) donors and among females 104 (34.67\%) donors as shown in Table-1.

The most common occupation among deferred were students (31\%), professional (19.65\%), unemployed (14.66\%) and services (11\%) as shown in Table-2.

Donor deferrals were tabulated into temporary and permanent as shown in Table-3 \&4. Temporary deferrals were 204(68\%) and permanent deferrals were 96(32\%). Among 204 (68\%) temporary deferrals, males were $55.4 \%$ and females were $44.6 \%$. Among males, the most common cause was under weight (30\%), anemia (26.55\%) and alcohol intake (21.24\%). In females, anemia (43.96\%), underweight $(24.18 \%)$ and hypotension(12.09\%) were the most common cause for temporary deferral. Among 96 (32\%) permanent deferrals, males were $83(86.45 \%)$ and females were $13(13.55 \%)$.The most common cause among males was hypertension $47(54.22 \%)$ followed by unexplained weight loss 16 (1715.66\%). In females asthma $12(30.77 \%)$ was the common cause for permanent deferral.

DISCUSSION: Adequate supply of blood is more important and it is also essential that the blood collection process does not harm either the donor or the recipient. This is achieved by donor selection criteria. ${ }^{[5]}$ The criteria is based on scientifically informed medical opinion and regulatory rules. Deferring donors protects both the blood donor and the recipient from harm. The rate and reasons of deferral differs from region to region and from one centre to other. Donor deferral rates in blood canters vary from 5 to 24\% leading to huge losses in terms of available units for transfusion in the nation every year.[6]

In the present study the overall deferred rate was $4.27 \%$ and the deferred rate was higher in males (65.33\%) compared to females (34.67\%).This was similar to that observed by Unikrishnan B ${ }^{11}(5.2 \%)$, Sundar $\mathrm{P}^{[3]}(6 \%)$, Agnihothri ${ }^{[5]}$ (11.6\%). The higher rate $(8-15 \%)$ was reported by Chaudhary[7], Lim ${ }^{[2]}$, Blumberg[8], Ranveet. ${ }^{[9]}$

In the Unikrishnan[1] study the VD deferred was $22.80 \%$, the findings was more in the present study (79\%).This was mainly observed in the students $(31 \%)$ and professionals (19.65\%), who by virtue of their education are more aware of the importance of blood donation. 
Students were the major donor population as they could be easily motivated and in the course could be retained for repeat VD.

Most of these deferred donors (74.33\%) were 18-38 years which was less compared to Shalini Bahadur (89.7\%) study. ${ }^{[10]}$ This highlights the fact that a sizeable proportion of youth in this part of the world are malnourished, reflecting the impact of low-socioeconomic status on the health of Indian youth. Donors above 60 years are not allowed to donate blood. Even otherwise it is rare to have a donor voluntarily coming to donate blood in our region. Where as in other countries there are many healthy voluntary blood donors $>60$ years of age who successfully donate blood. Garry et al[11], advice elderly healthy individual to donate but limit donations to less than five per year or donors are advised to take iron supplement regularly to preserve reasonable amount of iron reserve.

Donor deferral was tabulated into temporary and permanent. Custer et al[12] reported $68.5 \%$ temporary and $31.5 \%$ permanent deferral which was similar to the present study. The temporary deferrals were more than permanent deferrals. The three most common cause of temporary deferrals in females are anemia, underweight, hypotension. In males underweight, anemia and alcohol intake were the three most common causes. A number of other studies showed anemia as the most common cause like Naveen Agnihothri [5]56\%, Arslan et al [12] $20.7 \%$, Halperin et al $46 \%{ }^{[13]}$ Nearly two third of these anemic donors were females highlighting the prevalence of anemia in general population among females and it is very prevalent in a developing country like India and this is a significant cause for deferrals among donors who came forward enthusiastically for donation, but were unable to donate. These donors can be recruited back into the donor pool if managed properly. Similarly in another Indian study by Chaudhary ${ }^{[7]}$ low weight $(32.3 \%)$ and low haemoglobin $(18.6 \%)$ were the two most common reason for deferral.

Among permanent deferrals- hypertension was the common cause in males which was similar to Sundar $\mathrm{P}^{[3]}$ study. Two Indian studies report that history of jaundice was the common cause of deferral in Chandigarh and Lucknow .[9,7]

Unsucessful phelebotomy due to poor vein, double puncture, collecting less quantity was nil( $(0 \%)$.Whereas Sunder ${ }^{[3]}$ reported $0.006 \%$ and Farrales ${ }^{[15]}$ reported higher rate of $0.5 \%$.

In the present study the replacement donors had less deferral rate as compared to voluntary donors. This may be due to knowledge about the possibility of deferral and awareness of deferral criteria may be responsible for lower deferral rate in RD. Similar observation were made by Zou et al. ${ }^{[16]}$

Analysis of donor deferral pattern indicates the impact of knowledge of deferral criteria in blood donors. The donor deferral rate can be reduced by educating the donors and providing information about the selection criteria. This results in better acceptability and there by less negative feeling about rejection in blood donation and more chance of future return.

CONCLUSION:This study showed that the incidence of donor deferral was $4.27 \%$ and most of the donors were young with the majority being students and voluntary donors than replacement donors. Temporary deferrals were more compared to permanent deferrals. The most common cause among temporary deferrals was anemia, underweight and hypotension. Hypertension was the commonest cause among permanent deferrals. The donor deferrals can be reduced by providing information and educating the donors. This reduces the negative feeling about blood donations and blood donor deferrals. 
ACKNOWLEDGEMENT: I thank our Director, Principal, Superintendent, Professor and HOD of pathology, VIMS, Bellary.

\section{REFERENCES:}

1. Unnikrishnan B, Rao P, Kumar N, Ganti S, Prasad R et al. Profile of blood donors and reasons for deferral in coastal South India. Australasian Medical Journal. 2011; 4(7):379385.

2. Lim JC, Tien SL, Ong YW. Main causes of pre-donation deferral of prospective blood donors in the Singapore blood transfusion service. Ann Acad Med Singapore. 1993; 22:326-31.[PubMed]

3. Sundar P, Sangeetha SK, Seema DM, Marimuthu P, Shivanna N. Pre-donation deferral of blood donors in South Indian set-up: An analysis. Asian J Transfus Sci.2010 July; $4(2): 112-115$.

4. Department of AIDS Control Ministry of Health and Family Welfare Government of India .Annualreport:2008-2009.Availablefrom:

http://nacoonline.org/upload/Publication/Annual Report NACO 2008-09.PDF.

5. Naveen Agnihotri. Whole blood donor deferral analysis at a center in Western India. Asian J Transfus Sci.2010; 4(2):116-122.

6. Tomasulo PA, Anderson AJ, Paluso MB, Gutschenritter MA, Aster RH. A study of criteria for blood donor deferral. Transfusion 2003;20(5):511-18.

7. Chaudhary RK, Gupta D, Gupta RK. Analysis of donor-deferral pattern in a voluntary blood donor population. Transfus Med. 1995;5:209-12.[PubMed]

8. Blumberg N, Shah I, Hoagland J, Shirer L, Katz AJ. Evaluation of individuals deferred from blood donation for medical reasons. Vox Sang.1982; 42:1-7.[PubMed]

9. Ranveet Kaur, Sabita Basu, Neelam Marwaha . A reappraisal of underlying causes in donor deferral. Ann Natl Acad Med Sci. 2002; 38:93-9.

10. Shalini Bahadur ,Sonal Jain, Ruchika K Goel, Sangetta Pahuji, Manjula Jain et al. Analysis of blood donor deferral characteristics in Delhi, India. Southeast Asian J Trop Med Public Health. 2009;40(5):1087-1091.

11. Garry PJ, Vander Jagt DJ, Wayne SJ, Koehler KH, Rhyne RL, Simon TL. A prospective study of blood donations in healthy elderly persons. Transfusion. 1991; 31: 86-92.

12. Custer B, Johnson ES, Sullivan SD, Hazlet TK, Ramsey SD, Hirschler NV, et al. Quantifying losses to the donated blood supply due to donor deferral and miscollection. Transfusion. 2004;44:1417-26.[PubMed]

13. Arslan 0 . Whole blood donor deferral rate and characteristics of the Turkish population. Transfus Med 2007; 17:379-83.

14. Halperin D, Baetens J, Newman B. The effect of short term temporary deferral on future blood donation. Transfusion. 1998;38:181-3.

15. Farrales FB, Stevenson AR, Bayer WL. Causes of disqualification in a volunteer blood donor population. Transfusion. 1997; 17:598-601.

16. Zou S, Musavi F, Notari EP, Rios JA, Trouern-Trend J, Fang CT. Donor deferral and resulting donor loss at the American Red cross Blood Services, 2001 through 2006. Transfusion. 2008; 39(3): 571-4.

Table -1 : Total number of blood donors deferred by age $\&$ sex 


\begin{tabular}{|c|c|c|c|}
\hline $\begin{array}{c}\text { Age } \\
\text { (years) }\end{array}$ & Male & Female & Total \\
\hline $18-28$ & 67 & 71 & $138(46 \%)$ \\
\hline $29-38$ & 61 & 24 & $85(28.33 \%)$ \\
\hline $39-48$ & 33 & 08 & $41(13.67 \%)$ \\
\hline $49-61$ & 35 & 01 & $36(12 \%)$ \\
\hline Total & $196(65.33 \%)$ & $104(34.67 \%)$ & $300(100 \%)$ \\
\hline
\end{tabular}

Table-2 Occupation of the blood donors deferred

\begin{tabular}{|l|c|c|c|}
\hline & Male & Female & Total \\
\hline Students & 41 & 52 & $93(31 \%)$ \\
\hline Professional & 52 & 07 & $59(19.65 \%)$ \\
\hline Agriculture & 14 & 0 & $14(4.66 \%)$ \\
\hline Labour & 20 & 0 & $20(6.66 \%)$ \\
\hline Services & 33 & 0 & $33(11 \%)$ \\
\hline Technical & 13 & 0 & $13(4.33 \%)$ \\
\hline Unemployed & 22 & 22 & $44(14.66 \%)$ \\
\hline Housewife & 0 & 23 & $23(7.38 \%)$ \\
\hline Others & 02 & 0 & $300(100 \%)$ \\
\hline Total & $196(65.33 \%)$ & $104(34.67 \%)$ & \\
\hline
\end{tabular}


Table-3 Permanent deferral by age $\&$ sex

\begin{tabular}{|c|c|c|c|c|c|c|c|c|c|c|c|c|}
\hline \multirow[t]{2}{*}{ Causes } & \multicolumn{2}{|c|}{$\begin{array}{c}18-28 \\
\text { yrs }\end{array}$} & \multicolumn{2}{|c|}{$\begin{array}{c}29-38 \\
\text { yrs }\end{array}$} & \multicolumn{2}{|c|}{$\begin{array}{c}39- \\
48 y r s\end{array}$} & \multicolumn{2}{|c|}{ 49-60yrs } & \multicolumn{2}{|c|}{ Total } & \multirow{2}{*}{$\begin{array}{c}\text { Gran } \\
\mathrm{d} \\
\text { Total }\end{array}$} & \multirow[t]{2}{*}{$\%$} \\
\hline & $\mathrm{M}$ & $\mathrm{F}$ & $\mathrm{M}$ & $\mathrm{F}$ & $\mathrm{M}$ & $\mathrm{F}$ & $\mathrm{M}$ & $\mathrm{F}$ & $\mathrm{M}$ & $\mathrm{F}$ & & \\
\hline Hypertensin & - & - & 15 & 02 & 08 & - & 22 & - & $\begin{array}{c}45 \\
(54.22 \%)\end{array}$ & $\begin{array}{c}02 \\
(15.38 \%)\end{array}$ & 47 & $48.96 \%$ \\
\hline Asthma & 02 & 03 & 04 & 01 & 02 & - & - & - & $\begin{array}{c}08 \\
(9.64 \%)\end{array}$ & $\begin{array}{c}04 \\
(30.77 \%)\end{array}$ & 12 & $12.50 \%$ \\
\hline Epilepsy & 01 & - & 02 & - & 01 & 01 & - & 01 & $\begin{array}{c}04 \\
(4.82 \%)\end{array}$ & $\begin{array}{c}02 \\
(15.38 \%)\end{array}$ & 06 & $06.25 \%$ \\
\hline $\begin{array}{l}\text { Diabetes } \\
\text { mellitus on } \\
\text { insulin }\end{array}$ & 01 & - & 02 & - & 03 & 01 & - & - & $\begin{array}{c}06 \\
(7.23 \%)\end{array}$ & $\begin{array}{c}01 \\
(7.69 \%)\end{array}$ & 07 & $07.29 \%$ \\
\hline Polycythemia & - & - & 01 & 01 & 01 & - & - & - & $\begin{array}{c}02 \\
(2.41 \%)\end{array}$ & $\begin{array}{c}01 \\
(7.69 \%)\end{array}$ & 03 & $03.13 \%$ \\
\hline $\begin{array}{l}\text { Unexplained } \\
\text { weight Loss }\end{array}$ & - & - & 05 & 03 & 02 & - & 06 & - & $\begin{array}{c}13 \\
(15.66 \%)\end{array}$ & $\begin{array}{c}03 \\
(23.08 \%)\end{array}$ & 16 & $16.67 \%$ \\
\hline $\begin{array}{l}\text { S/S suggestive } \\
\text { of AIDS }\end{array}$ & 02 & - & 02 & - & 01 & - & - & - & $\begin{array}{c}05 \\
(6.02 \%)\end{array}$ & $(0.00)-$ & 05 & $05.21 \%$ \\
\hline Total & 06 & 03 & 31 & 7 & 18 & 2 & 28 & 01 & $\begin{array}{c}83 \\
(100 \%)\end{array}$ & $\begin{array}{c}13 \\
(100.00)\end{array}$ & 96 & $100 \%$ \\
\hline
\end{tabular}

Table-4:Temporary deferral by age and sex 


\begin{tabular}{|c|c|c|c|c|c|c|c|c|c|c|c|}
\hline \multirow[t]{2}{*}{ Causes } & \multicolumn{2}{|c|}{$18-28$ Yrs } & \multicolumn{2}{|c|}{ 29-38 Yrs } & \multicolumn{2}{|c|}{$39-48$ yrs } & \multicolumn{2}{|c|}{ 49-60yrs } & \multicolumn{2}{|c|}{ Total 204cases } & \multirow[t]{2}{*}{ Grand Total } \\
\hline & $\mathrm{M}$ & $\mathrm{F}$ & $\mathrm{M}$ & $\mathrm{F}$ & $\mathrm{M}$ & $\mathrm{F}$ & $\mathrm{M}$ & $\mathrm{F}$ & M & $\mathrm{F}$ & \\
\hline Anemia & 23 & 38 & 04 & 02 & 03 & - & - & - & $\begin{array}{c}30 \\
(26.55 \%)\end{array}$ & $\begin{array}{c}40 \\
(43.96 \%)\end{array}$ & $70(34.31 \%)$ \\
\hline Underweight & 18 & 22 & 16 & - & - & - & - & - & $\begin{array}{c}34 \\
(30.00 \%)\end{array}$ & $\begin{array}{c}22 \\
(24.18 \%)\end{array}$ & $56(27.45 \%)$ \\
\hline Hypotension & - & 02 & - & 09 & - & - & - & - & $(0.00)$ & $\begin{array}{c}11 \\
(12.09 \%)\end{array}$ & $11(5.39 \%)$ \\
\hline $\begin{array}{l}\text { Fever due to } \\
\text { bacterial } \\
\text { viral,fungal } \\
\text { infections }\end{array}$ & - & - & 04 & 01 & 04 & 05 & 01 & - & $\begin{array}{c}09 \\
(7.96 \%)\end{array}$ & $\begin{array}{c}06 \\
(6.59 \%)\end{array}$ & $15(7.35 \%)$ \\
\hline Lactation & - & 03 & - & - & - & - & - & - & $(0.00)$ & $\begin{array}{c}03 \\
(3.30 \%)\end{array}$ & $03(1.47 \%)$ \\
\hline Menstruations & - & 02 & - & 05 & - & 01 & - & - & $(0.00)$ & $\begin{array}{c}08 \\
(8.79 \%) \\
\end{array}$ & 08(3.92\%) \\
\hline Abortion & - & 01 & - & - & - & - & - & - & $(0.00)$ & $\begin{array}{c}01 \\
(1.10 \%)\end{array}$ & $01(0.49 \%)$ \\
\hline History of icterus & 01 & - & 02 & - & - & - & - & - & $\begin{array}{c}03 \\
(2.65 \%)\end{array}$ & $(0.00)$ & $03(1.47 \%)$ \\
\hline $\begin{array}{l}\text { History of blood } \\
\text { transfusion }\end{array}$ & - & - & 01 & - & 01 & - & - & - & $\begin{array}{c}02 \\
(1.77 \%) \\
\end{array}$ & $(0.00)$ & $02(0.98 \%)$ \\
\hline Typhoid fever & - & - & 01 & - & - & - & - & - & $\begin{array}{c}01 \\
(0.88 \%)\end{array}$ & $(0.00)$ & $01(0.49 \%)$ \\
\hline Alcohol intake & 18 & - & 02 & - & 04 & - & - & - & $\begin{array}{c}24 \\
(21.24 \%) \\
\end{array}$ & $(0.00)$ & $24(11.76 \%)$ \\
\hline Drug intake & 01 & - & - & - & 03 & - & 06 & - & $\begin{array}{c}10 \\
(8.85 \%)\end{array}$ & $(0.00)$ & $10(4.90 \%)$ \\
\hline Total & 61 & 68 & 30 & 17 & 15 & 06 & 7 & - & $\begin{array}{c}113 \\
(100 \%)\end{array}$ & $\begin{array}{c}91 \\
(100 \%)\end{array}$ & $\begin{array}{c}204 \\
(100 \%)\end{array}$ \\
\hline
\end{tabular}

